\title{
Досвід психосоціальної реабілітації осіб із психічними розладами на базі Сватівської обласної психіатричної лікарні
}

\author{
Вінтоняк Д. М., Новохатська О. В., Ямпольська О. В., Луганська І. В., Кривоніс О. О. \\ К3 "Сватівська обласна психіатрична лікарня", м. Сватово, Луганська область, Україна (!)
}

Ключові слова: психосоціальна реабілітація; психічні розлади; мультидисциплінарна бригада.

Психічне здоров'я - найдорожче, що $€$ у людини. Саме психічне здоров'я робить людину повноцінним членом суспільства. Психічне або душевне здоров'я, згідно з визначенням Всесвітньої організації охорони здоров'я - це стан благополуччя, при якому людина може реалізувати свій власний потенціал, справлятися зі звичайними життєвими стресами, продуктивно і плідно працювати, а також робити внесок у життя своєї спільноти.

В умовах сучасного стану розвитку психіатричної галузі проблема надання допомоги хворим із психічними розладами займає важливе місце. Це зумовлено не тільки збільшенням кількості осіб, що страждають на цю патологію, а й багатьма соціальними, економічними факторами, особливостями розвитку суспільства та його ставлення до пацієнтів із психічними проблемами. В таких умовах пріоритетними завданнями психіатрії $є$ використання не тільки психофармакологічних засобів, але й методи реабілітаційного характеру, в основі яких лежить біосоціальна модель надання психіатричної допомоги з впровадження методів психологічного впливу, що спрямовані на реінтеграцію особистості, формування адаптивного самовдосконалення та ставлення до своєї хвороби, розвиток адаптивних властивос- тей на фоні наявних патопсихологічних рис. Хочемо показати, що в першу чергу психіатрична лікарня - це місце, де надається висококваліфікована медична, психологічна та соціальна допомога. Завдання допомогти людині залишитися повноцінним членом суспільства, а суспільству - по-іншому подивитися на людину, яка страждає цим розладом та прагне співчуття і розуміння у суспільстві. Сьогодні психосоціальна реабілітація набуває все більшої популярності. Основна мета реабілітаційних заходів полягає в тому, щоб особа, яка страждає на психічні розлади, залишалась соціально активною. Досягнення вищевказаної мети відбувається насамперед через залучення психічно хворих у реабілітаційні процеси та соціальне життя, вирішення ïх медичних, побутових та соціальних проблем, підвищення працездатності, рівня самообслуговування та досягнення найбільш повної соціальної адаптації. Шляхом досягнення мети вирішуються наступні завдання:

- Забезпечити людям із психічними захворюваннями інформаційну підтримку, завдяки якій вони отримають можливість зрозуміти, як жити 3 душевним розладом.

- Навчити пацієнтів висловлювати свої думки і почуття, допомогти подолати апатію і безініціативність, сформувати активнішу життєву позицію.

- Організувати продуктивне проведення часу для подолання соціальної 
ізоляції, придбання нових інтересів і захоплень, підвищення самооцінки.

- Дати можливість практикуватися в основних соціальних і життєвих навичках.

- Сприяти створенню терапевтичного середовища в лікарні.

Комплексність медичної, психологічної, соціальної допомоги забезпечується використанням у роботі мультидисциплінарного підходу - при одночасному реабілітаційному втручанні медичних працівників, психологів, інструкторів 3 праці, соціальних та інших працівників.

На базі Сватівської обласної психіатричної лікарні з 2014 року розпочала свою роботу мультидисциплінарна бригада у складі лікаря-психіатра, практичного психолога, соціального працівника. Лікар формує групу, психолог організовує тренінги та здійснює психологічний супровід на виїзних тренінгах. Соціальний працівник здійснює виїзні тренінги, спрямовані на відпрацювання самостійних соціальних навичок. Внутрішньолікарняні тренінги складаються 3 музичної терапії (1 година на тиждень), стимуляції творчого потенціалу (заняття 3 орігамі, малювання, ліплення, майстер-класи). Ці види тренінгів проводяться силами волонтерів та небайдужих співробітників лікарні, 2 рази на тиждень. Комунікативні тренінги, тренінги міжособистісної взаємодії, проводяться психологом - 1 раз на тиждень. У теплі пори року можуть проводитись на вулиці, зокрема збір лікарських трав, ягід.

Регулярно проводяться оздоровчі прогулянки з метою підняття та підтримки емоційного фону пацієнтів. Привиття навичок соціального функціонування, тренінги догляду за собою - прибирання, вирощування квітів та овочевих культур - проводяться силами середнього та молодшого медичних персоналів відділень. Спортивні тренінги (заняття тенісом, вправи на перекладині тощо) проводяться самостійно хворими. Бібліотерапія проводиться за ініціативою хворих. Один раз на тиждень - кінопоказ. Виїзні тренінги проводяться на базі музею, етноцентру «Слобожанська хата». Анімалотерапія проводиться на базі кінного спортивного клубу, а також при відвідуванні виставок домашніх та свійських тварин.
Під час тренінгів закріплюються навички проїзду в міському транспорті, планування бюджету та розпорядження власними коштами, навички працювати 3 банківською карткою, відвідання місць 3 великим скупченням людей, де головним $€$ формування навичок комунікації.

Звичайним у психосоціальній реабілітації $€$ етапність i закріплення досягнутих результатів шляхом неодноразових повторень. Для пацієнтів, які проходили курс психосоціальних заходів, були підібрані опитувальники, які грунтувалися на принципах психосоціальної реабілітації і полягали насамперед у центрації на людині як цілісності, поважанні її компетенції, спрямованості на процес і націленості на взаємодію та діалог. Для визначення ефективності запланованих та проведених психореабілітаційних заходів використовували психометричну шкалу оцінки вираженості позитивних, негативних та загальних психопатологічних симптомів (SAPS), шкалу оцінки рівня самостигматизації та методи статистичної обробки отриманих даних. у кількості 30 осіб, з якими на етапі стабілізуючої терапії проводилися різноманітні тренінги. До досліджуваної групи входили хворі на шизофренію, 24 особи (80\%), пацієнти, які мали психічні захворювання внаслідок органічних захворювань головного мозку, 3 особи (10\%), і пацієнти 3 розумовою відсталістю, 3 особи (10\%). Крім цього, була досліджена аналогічна за структурою психічних розладів група пацієнтів (у кількості 15 осіб), які отримували лише психофармакологічну терапію.

Психометричний профіль обстежених груп хворих та його динаміка наведені в таблиці.

Порівнюючи результати контрольної групи та досліджуваної групи, ми отримали наступні результати:

- Збільшення тривалості ремісії. Середня тривалість ремісії контрольної групи - до 5 місяців, а досліджуваної групи - до 9 місяців.

- Поява комплаєнсу. Серед досліджуваної групи немає відмов від підтримуючого лікування, тоді як в контрольній групі $40 \%$ відмовились від нього в домашніх умовах. У досліджуваній групі в подальшій госпіталізації пацієнти давали добровільну 


\begin{tabular}{clccc}
\hline \multirow{2}{*}{$\begin{array}{c}\text { № } \\
3 \backslash \Pi\end{array}$} & \multicolumn{1}{c}{$\begin{array}{c}\text { Досліджувані } \\
\text { сфери }\end{array}$} & \multicolumn{2}{c}{ Досліджувана група (\%) } & Контрольна \\
\cline { 3 - 4 } & \multicolumn{1}{c}{ др реабілітації } & після реабілітації & груп \\
\hline 1 & Активне життя & 44 & 85 & 39 \\
\hline 2 & $\begin{array}{l}\text { Здоров’я (відношення до хвороби } \\
\text { як до трагедії) }\end{array}$ & 82 & 26 & 80 \\
\hline 3 & Цікава робота & 0 & 67 & 0 \\
\hline 4 & Краса природи і мистецтва & 46 & 94 & 42 \\
\hline 5 & Кохання, любов та дружні почуття & 16 & 57 & 14 \\
\hline 6 & Матеріально забезпечене життя & 27 & 54 & 31 \\
\hline 7 & Наявність хороших і вірних друзів & 19 & 37 & 16 \\
\hline 8 & Упевненість у собі & 24 & 63 & 23 \\
\hline 9 & Пізнання & 19 & 74 & 18 \\
\hline 10 & Незалежність у вчинках і діях & 39 & 83 & 37 \\
\hline 11 & Щасливе сімейне життя & 18 & 33 & 16 \\
\hline
\end{tabular}

згоду на лікування, тоді як у контрольній групі - чотири випадки примусової госпіталізації.

- Активація проявів самостійності. Пацієнти в досліджуваній групі не мали проблем 3 виходом у громадські місця, порівняно 3 контрольною групою, де відзначалися страхи відвідування публічних місць (магазини, пошта, лікарня). Пацієнти з досліджуваної групи зазначали, що хоча б раз за період перебування вдома відвідували концерти, музеї, бібліотеки, кафе. У пацієнтів 3 контрольної групи взагалі не відзначалась громадська активність. 12 пацієнтів із досліджуваної групи постійно відвідують гуртки та секції. З'явився інтерес до колишніх захоплень: написання віршів, малювання, вишивки, співи. Родичі відзначають підвищення емоційності та емпатії у своїх близьких, які під час перебування в лікувальному закладі відвідували психосоціальні реабілітаційні заходи. Слід відзначити появу інтересу до працевлаштування: 6 осіб звертались на біржу праці, 2 осо- би працюють на місцях, облаштованих для людей 3 інвалідністю, 1 особа працює за трудовим договором. Більше половини досліджуваних упродовж перебування вдома виконували разові роботи за гроші. У контрольній групі такої активності не відзначалося.

Отже, встановлено, що проведення фармакологічної терапії обов'язково має поєднуватися 3 різноманітними психосоціальними реабілітаційними заходами, тому що останні спрямовані безпосередньо на особистість пацієнта. Ефективність реабілітації зумовлена підвищенням соціальної адаптації хворих, поліпшенням інтегральної самооцінки та зменшенням вираженості загальної симптоматики захворювань пацієнтів. Результати проведеного дослідження варто враховувати під час проведення психокорекційних заходів для осіб із розладами психіки. В подальшому ми плануємо впроваджувати нові методи у психосоціальну реабілітаційну діяльність.

Список літератури знаходиться в редакції (прим. ред.) 